\title{
Ceratobasidium ramicola IBRLCM127, an endophytic fungus isolated from Curcuma mangga Valeton \& Zijp with strong anti-candidal activity
}

\author{
Kharul Azmi Mu'azzam Abdul Rahman ${ }^{1 *}$, Darah Ibrahim² \\ ${ }^{1}$ Faculty of Agro Based Industry, Universiti Malaysia Kelantan, Kelantan, Malaysia. \\ ${ }^{2}$ Industrial Biotechnology Research Laboratory, Universiti Sains Malaysia, Penang, Malaysia.
}

\begin{tabular}{l}
\hline ARTICLE INFO \\
\hline Received on: 11/05/2019 \\
Accepted on: 26/08/2019 \\
Available online: 04/11/2019 \\
\hline Key words: \\
Ceratobasidium ramicola \\
IBRLCM127, endophytic \\
fungus, anti-candidal activity, \\
Curcuma mangga, Candida \\
albicans
\end{tabular}

\section{INTRODUCTION}

The incidence of invasive and opportunistic fungal infections for the past few decades has shown a dramatic increase resulting in the higher rate of morbidity and mortality (Miceli et al., 2011). Approximately, $95 \%$ of fungal infections in human are caused by Candida species, particularly Candida albicans that can cause the life-threatening disease called candidiasis if it reaches human bloodstream (Kaufman, 2012).

Candida albicans is a polymorphic fungus with the ability to alternately switch in between a round and long straggly structure that enable the cell to be successfully adapting

${ }^{*}$ Corresponding Author

Kharul Azmi Mu'azzam Abdul Rahman, Faculty of Agro Based Industry, Universiti Malaysia Kelantan, Kelantan, Malaysia.

E-mail:muazzam_master@yahoo.com to various kinds of environmental conditions and making it extraordinarily harmful. Candidal infections or candidiasis is one of the antecedents in all major fungal infections of which these infections have been identified as the leading cause of death among immunocompromised patients and also including those that have been treated with broad-spectrum antibiotics, immunosuppressive agents, undergone organ transplantation, intensive care of low birth weight infants, and HIV-infected (Chapman et al., 2017). Some strains of Candida sp., particularly C. albicans have developed resistance towards conventional antifungal treatment. For example, in 2013, fluconazole-resistant $C$. albicans was reported to be the main threat of fungal infections with approximately 3,400 candidal infection cases annually (Centers for Disease Control and Prevention, 2013). Therefore, drug-resistant yeast and fungi could pose a serious threat to mankind which demands immediate alternative strategies to search for novel antibiotics to tame this problem. In this case, endophytes are depicted as an outstanding 
source of medicinally important compounds that can offer a new horizon of drug-resistance dilemma (Levy, 2005).

Endophytes are microorganisms (bacteria, yeast, and fungi) that live inside the healthy host plant tissues without posing any apparent symptoms or diseases (Yu et al., 2010). Due to the long co-evolution of endophytic microorganisms with its plant host, they possess the ability in synthesizing bioactive metabolites originally associated with their host plants and it has been acknowledged as an important source of novel drug discovery (Lam, 2007). The pharmacologically bioactive compounds produced by endophytes show a high level of structural diversity and have been proven to exhibit antimicrobial, antitumor, antioxidant, antiviral, and antifungal properties that offer a tempting source of drugs with less adverse effect to human (Alvin et al., 2014; Berger, 2009).

Based on the aforementioned facts above, the attempt to discover a novel anti-candidal agent from natural source is proceeded in this study by investigating the potential of secondary metabolites of Ceratobasidium ramicola IBRLCM127, a fungal endophyte previously recovered from the rhizome of local medicinally important plant Curcuma mangga Valeton \& Zijp against $C$. albicans.

\section{MATERIALS AND METHODS}

\section{Culture and maintenance of the endophytic fungus}

The endophytic fungus $C$. ramicola IBRLCM127 which was previously isolated from the rhizome of $C$. mangga Val \& Zijp was supplemented by the division of culture collection of Industrial Biotechnology Research Laboratory, School of Biological Sciences, Universiti Sains Malaysia, Penang, Malaysia. This isolate was cultured on Potato Dextrose Agar supplemented with host plant powder $\left(5 \mathrm{gl}^{-1}\right)$ and incubated at $30^{\circ} \mathrm{C}$ for 6 days. The isolates were then stored at $4{ }^{\circ} \mathrm{C}$ prior to the usage. This isolate was cultured routinely on a fresh agar media once a month to ensure the cell is viable and pure.

\section{Culture medium}

Yeast extract sucrose broth was prepared containing $\left(\mathrm{gl}^{-1}\right)$ : yeast extract, 20; sucrose, 40; and magnesium sulfate, 0.5 mixed uniformly with $1,000 \mathrm{ml}$ distilled water supplemented with C. mangga extract. The preparation of extract was done via 30 minutes of boiling of $10 \mathrm{~g}$ of the plant powder in $500 \mathrm{ml}$ distilled water, followed by filtration of the mixture using Whatman No. 1 filter paper and mixing the filtrate with fresh culture medium. The $\mathrm{pH}$ mixture was adjusted to 5.8 and autoclaved for 15 minutes at $121^{\circ} \mathrm{C}$ prior to the usage in cultivating fungal endophyte isolates using the shake-flask system.

\section{Cultivation and extraction}

Two mycelial agar plugs (diameter $1.0 \mathrm{~cm}$ and thickness $4.0 \mathrm{~mm}$ ) from 6-day old culture of the fungal isolate were introduced into $250 \mathrm{ml}$ Erlenmeyer flasks consisting of YES broth $(100 \mathrm{ml})$. This culture was incubated at $30^{\circ} \mathrm{C}, 120 \mathrm{rpm}$ for 20 days under the dark condition. Next, Whatman no 1 filter paper was used to separate out the fermentative broth and fungal biomass. The fermentative broth was subjected to the extraction process using the same volume of ethyl acetate $(1: 1 ; \mathrm{v} / \mathrm{v})$ thrice. The organic phase (upper part) was collected and concentrated to dryness using rotary evaporator under the reduced pressure to get the paste form of ethyl acetate extract. A sterile medium was prepared as a control using a similar process as in endophytes culture preparation due to the biological activity possessed by $C$. mangga. The fungal biomass, on the other hand, was freeze-dried and macerated overnight in methanol $(1: 50 ; \mathrm{w} / \mathrm{v})$. The mixture was then filtered using Whatman no 1 filter paper followed by concentrating using rotary evaporator to get crude methanolic extract in a paste form.

\section{Test microorganisms and culture maintenance}

The stock culture of $C$. albicans was obtained from the culture collection of IBRL, School of Biological Sciences, Universiti Sains Malaysia, Penang, Malaysia. This cultural stock was stored as $20 \%$ glycerol stock in $-20^{\circ} \mathrm{C}$ freezer and maintained routinely by sub-culturing once a month on sabouraud Dextrose Agar (SDA) followed by incubating process under designated conditions $\left(37^{\circ} \mathrm{C}, 24\right.$ to 48 hours).

The preparation of $C$. albicans inoculum was done by picking up 3 to 5 pure colonies of 24- to 48-hours-old culture and transferred into universal bottle consisting of $10 \mathrm{ml}$ of sterile physiological saline $(0.85 \% \mathrm{NaCl}, \mathrm{w} / \mathrm{v})$, followed by vortex of a mixture for uniform mixing and adjusted the turbidity by using McFarland standard.

\section{Disk diffusion assay}

The assay method was conducted as proposed by EspinolIngroff (2007). A $100 \mu \mathrm{l}$ of suspension containing $1 \times 10^{6} \mathrm{CFU} /$ $\mathrm{ml}$ of $C$. albicans cells was spread onto SDA using a sterile cotton swab. Sterile antibiotic disk (6.0 $\mathrm{mm}$ diameter) impregnated with $20 \mu \mathrm{l}$ of crude extract of both ethyl acetate and methanol at the concentration of $50 \mathrm{mgml}^{-1}$ (dissolving in 5\% dimethyl sulfoxide) were placed onto the seeded agar surface. Negative control of $5 \%$ dimethyl sulfoxide used to detect the solvent effects, while positive control consists of $30 \mu \mathrm{gml}^{-1}$ ketoconazole. These plates were incubated $\left(37^{\circ} \mathrm{C}, 24\right.$ hours) and the diameter of clear zone around the disk was measured. This experiment was carried out in three replicates on separate occasions.

\section{MIC and MYC determination}

Broth microdilution technique was performed in sterile 96-well microtiter plate to determine the minimum inhibitory concentration (MIC) (Nor Afifah et al., 2010). The prepared inoculum was diluted using sterile physiological saline $(0.85 \%$ $\mathrm{NaCl} . \mathrm{w} / \mathrm{v}$ ) and adjusted to the inoculum size of $5 \times 10^{4} \mathrm{CFU} /$ $\mathrm{ml}$. The fungal extract was subjected to two-fold serial dilution using sterile Sabouraud dextrose broth (SDB) medium as a diluent to yield the final extract concentrations ranging from 0.0098 to $5.0000 \mathrm{mgml}^{-1}$. The control of an experiment consisting of the mixture of sterile SDB medium and inoculum. The plates were incubated for 24 hours at a temperature of $37^{\circ} \mathrm{C}$. Next, $40 \mu \mathrm{l}$ of $0.2 \mathrm{mgml}^{-1} \mathrm{p}$-iodonitrotetrazolium violet salt (INT) was added into each well as a growth indicator which is shown by the purple color of INT. The MIC value was determined as the lowest concentration of extract that inhibited the growth of yeast cell, while the determination of minimum yeastocidal concentration (MYC) performed by taking out a sample volume of $100 \mu \mathrm{L}$ from each treatment well and diluted accordingly prior to streaking on SDA plate to determine the viability of the cells (Tong et al., 2012). 
The MYC was defined as the lowest concentration of extract that was able to kill $99.9 \%$ of yeast cells as compared to control.

\section{Time-kill curve study}

The experiment was conducted following the protocol proposed by CLSI (2006) with some modifications. The C. albicans suspension was prepared by picking up 3-5 colonies from 16 to 24 hours old $C$. albicans culture and aseptically transferred them into the $20.0 \mathrm{ml}$ SDB followed by incubation process under designated condition $\left(37^{\circ} \mathrm{C}, 150 \mathrm{rpm}\right.$, and 16 to 18 hours $)$. The cells' turbidity during the log phase was measured using spectrophotometer $(625$ $\mathrm{nm}$ wavelength). The extract was mix with $25 \mathrm{ml}$ of SDB in $50 \mathrm{ml}$ Erlenmeyer flask to obtain the desired concentration of extract, viz., 0 (control), 1.25 (half MIC), 2.50 (MIC), and 5.00 (2 MIC) $\mathrm{mgml}^{-1}$ after the addition of the yeast inoculum (Yogalatha et al. 2010). The inoculated flasks were incubated in an orbital shaker at $37^{\circ} \mathrm{C}$ with agitation speed of $150 \mathrm{rpm}$. At predetermined time intervals, a $100 \mu \mathrm{l}$ aliquot from each treatment flask was pipetting out for viable cell count at every 4 hourly during the time intervals of $0-48$ hours. The samples were diluted and spread onto fresh SDA plates prior to incubation process $\left(37^{\circ} \mathrm{C}, 24\right.$ hours $)$ to determine colony-forming unit per milliliter $\left(\mathrm{CFUml}^{-1}\right)$, only the plates with the number of colonies ranging from 30 to 300 were counted. A curve for time-kill study $\left(\log \mathrm{CFUml}^{-1} v s\right.$. time) was plotted for each concentration of extract including control. The experiment was carried out in triplicates on separate occasions.

\section{Structural degeneration of the $\mathrm{C}$. albicans cells treated with ethyl acetate extract}

The preparation of C. albicans suspension was mentioned previously. The mixing of suspension with extract solution was performed to yield the final concentration of $2 \mathrm{MIC}\left(5.00 \mathrm{mgml}^{-1}\right)$ in the flask and these flasks were then incubated accordingly $\left(37^{\circ} \mathrm{C}\right.$, $150 \mathrm{rpm}$ ). The harvesting process of cultures was carried out at 0 and 36 hours of incubation time prior to subjected to scanning electron microscope (SEM) (Leica Cambridge, S-360, UK) and transmission electron microscope (TEM) (LIBRA@120 EFTEM, Germany) observations as mentioned by Borges et al. (1989) and Mares (1989).

\section{Statistical analysis}

The data were analyzed by Student $t$-test to compare the effect of ethyl acetate extract on pathogen using SPSS Version 12.0. The tests were performed independently in three replicates. The results in the current study were analyzed using a one-way analysis of variance and presented as the mean $\pm \mathrm{SD}$.

\section{RESULTS}

The disk diffusion susceptibility assay was employed to investigate the anti-candidal activity of fungal endophyte $C$. ramicola IBRLCM127 recovered from the rhizome of C. mangga and the result was shown in Table 1 . The result revealed that only ethyl acetate extract exhibited anti-candidal activity with $15.3 \pm$ $0.6 \mathrm{~mm}$ diameter of inhibition zones while no activity was detected for methanolic extract, suggesting that the bioactive compound(s) with anti-candidal activity was secreted extracellularly into the fermentative medium.

The MIC and MYC values of ethyl acetate extract towards $C$ albicans were recorded in Table 2. In most cases involving studies of microorganisms, the MYC values are always equal or higher than MIC values, meaning that the concentration of extract must be increased significantly to successfully kill the pathogen cells. In this case, the extract was exerted a bactericidal effect as the ratios of MYC/MIC were $\leq 4$ (Table 2). The result from the broth microdilution technique demonstrated that the technique employed was more sensitive and very useful to evaluate the extract susceptibility against the tested microorganism.

The time-kill curve of the ethyl acetate extract from C. ramicola IBRLCM127 towards C. albicans was depicted in Figure 1, in which the growth curve for control shows four different growth phases consisting of lag, exponential, stationary, and death phases. However, this growth curve changed significantly with the addition of the fungal extract. As the concentration of extract increased, the growth of candida in term of colony-forming units was reduced. No post-antibiotic effect was observed for all the concentration tested in this study. At half MIC value $(1.25 \mathrm{mg} /$ $\mathrm{ml})$ and MIC value $(2.5 \mathrm{mg} / \mathrm{ml})$, the effects were yeastostatic, whereas at the $2 \mathrm{MIC}$ value $(5.0 \mathrm{mg} / \mathrm{ml})$, the effect observed was yeastocidal. At $2 \mathrm{MIC}$ value, the extract was able to successfully reduce the cell number from the initial inoculum proving that the potency of the extract as anticandidal agent against $C$. albicans.

The detail observations of morphological changes of $C$. albicans cells caused by extract were done via SEM and TEM. Figure 2 depicts the photomicrographs from SEM observation representing the effect of ethyl acetate extract derived from fungal

Table 1. Anti-candidal activity of the crude ethyl acetate and methanolic extracts of $C$. ramicola IBRLCM127 against $C$. albicans.

\begin{tabular}{lcccc}
\hline \multirow{2}{*}{ Tested yeast } & \multicolumn{4}{c}{ Diameter of inhibition zone $(\mathbf{m m})$} \\
\cline { 2 - 5 } & $\begin{array}{c}\text { Ethyl acetate } \\
\text { extract }\end{array}$ & $\begin{array}{c}\text { Methanolic } \\
\text { extract }\end{array}$ & $\begin{array}{c}\text { Positive } \\
\text { control }\end{array}$ & $\begin{array}{c}\text { Negative } \\
\text { control }\end{array}$ \\
\hline C. albicans & $15.3 \pm 0.6$ & - & $20.3 \pm 0.6$ & - \\
\hline
\end{tabular}

Table 2. MIC and MYC values $(\mathrm{mg} / \mathrm{ml})$ of ethyl acetate extract from C. ramicola $\mathrm{IBRLCM} 127$.

\begin{tabular}{lccc}
\hline $\begin{array}{l}\text { Test } \\
\text { microorganism }\end{array}$ & MIC $(\mathbf{m g} / \mathbf{m l})$ & MYC $(\mathbf{m g} / \mathbf{m l})$ & Ratio MYC:MIC \\
\hline C. albicans & 2.5 & 2.5 & 1 (Bactericidal) \\
\hline
\end{tabular}

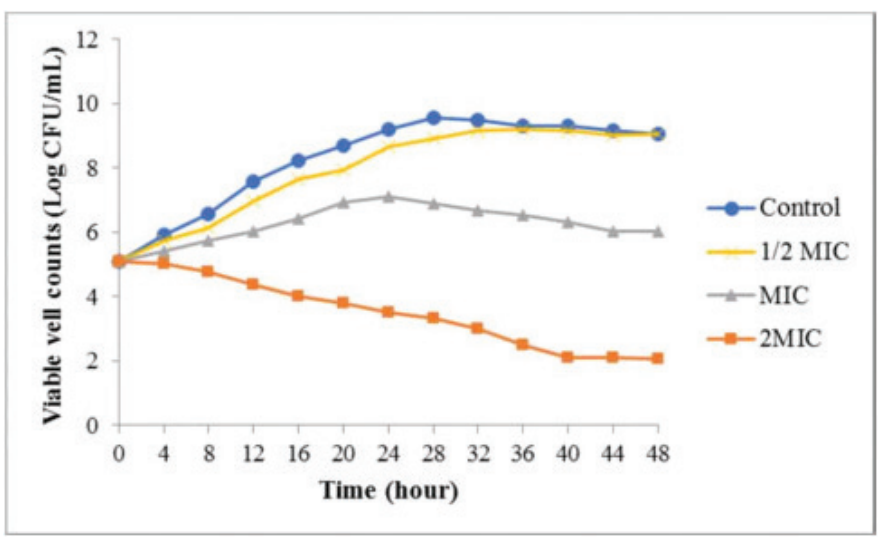

Figure 1. Time-kill curve study on Candida albicans cells by the ethyl acetate extract of C. ramicola IBRLCM127. 

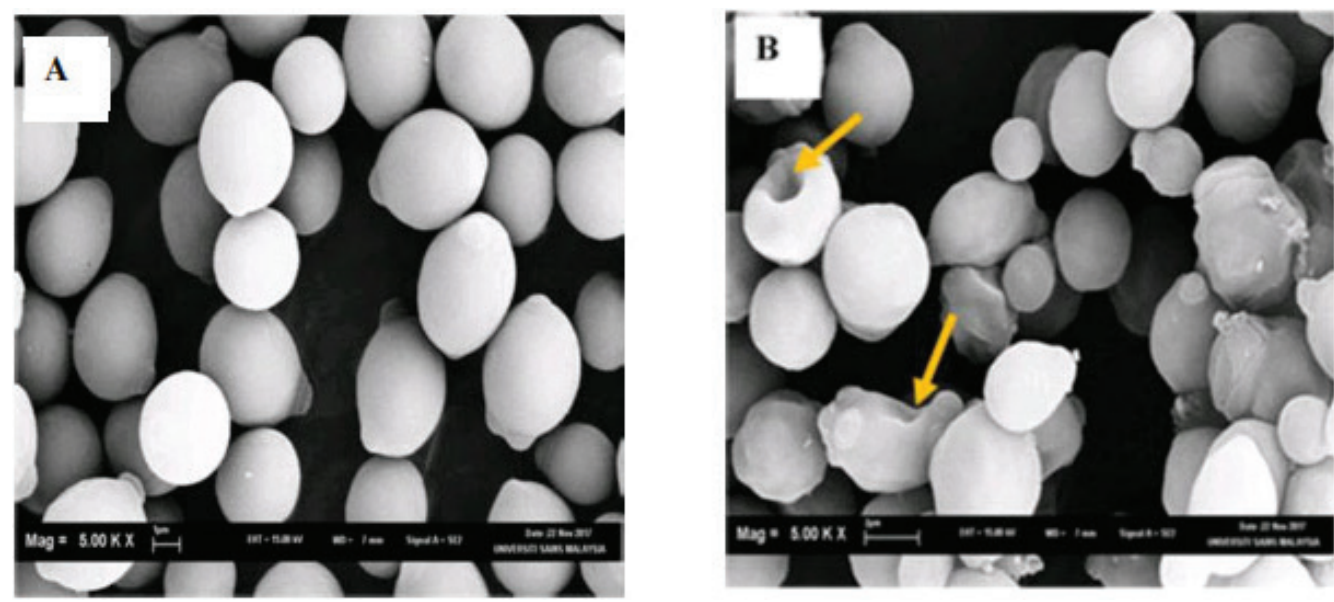

Figure 2. SEM photomicrographs of C. albicans cells. (A) untreated cell (control) and (B) treated cell with ethyl acetate extract of $C$. ramilcola IBRLCM127 at 2MIC value $(5.0 \mathrm{mg} / \mathrm{ml})$ and 36 hours of exposure time. Magnifications 5,000×. Arrows indicated the morphological and distinct feature changes occurred to the cells.

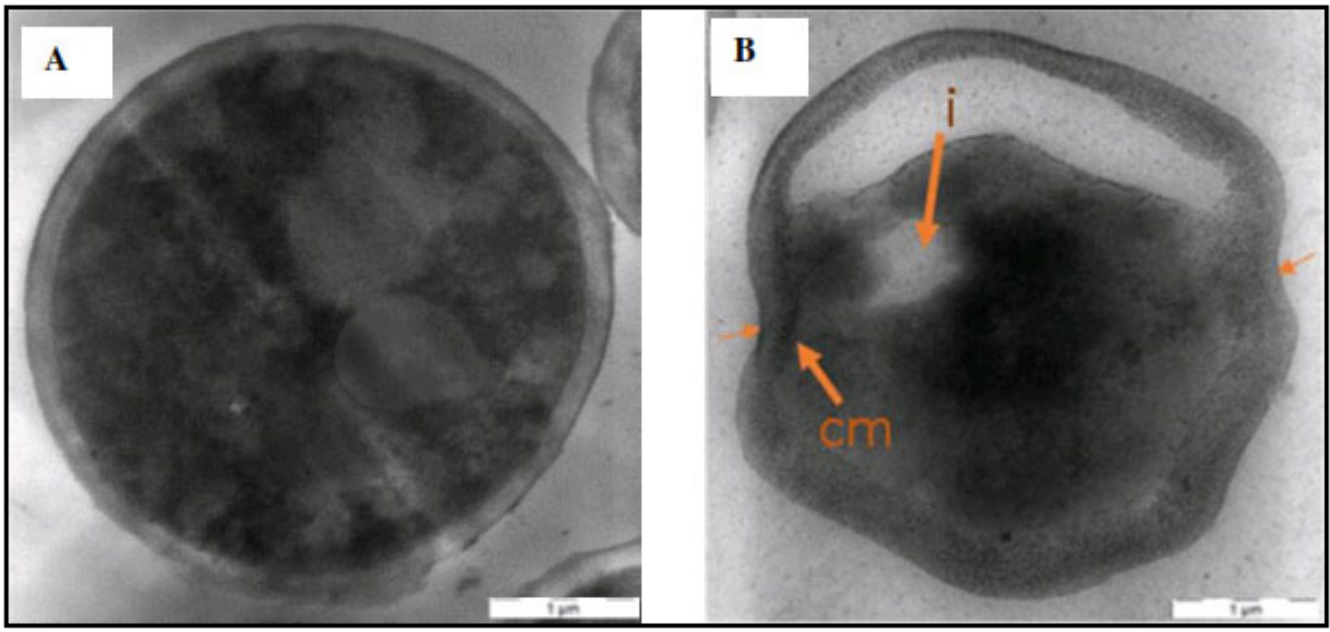

Figure 3. TEM photomicrographs of C. albicans cells. (A) untreated cell (control) and (B) treated cell with ethyl acetate extract of C. ramicola IBRLCM127 at 2MIC value $(5.0 \mathrm{mg} / \mathrm{ml})$ and 36 hours of exposure time. Damage at cell wall is indicated with small arrows in (B).

endophyte C. ramicola IBRLCM127 toward C. albicans cells. Figure 2A indicates most of the C. albicans cells were appeared to be in oval and smooth state with some at a budding stage (control or untreated cells). On the contrary, most of the treated cells with 36 hours of exposure time to the extract (Fig. 2B) were shrunken and starting to collapse, meaning that most of the cells lost their intact oval structures. At this stage, the cell damage was beyond repair and the cells completely lost their metabolic function.

For a closer view, a TEM study was performed (Fig. 3). Figure 3A shows a typical structure of a control or untreated $C$. albicans cells which possessed cytoplasm with cells organelles suspending within it, and surrounded by the cell membrane and cell wall. On the other hand, there was a deformation and stunted budding formation for the 36 hours extract treated cell (Fig. 3B). The cytoplasm had migrated to the periphery of the cell and leaked out probably due to the imbalance of osmotic pressure caused by the cell membrane permeability alteration. At this point, the cell membrane was partially disintegrated especially in the area close to the budding site. Inclusions also can be observed at a budding site of a damaged cell which then led to cell lysis.

\section{DISCUSSION}

There has been an increasing number of yeasts that are developing resistance towards antifungal drugs available in the market nowadays, particularly C. albicans that have been reported to develop resistance towards amphotericin B and fluconazole (Odds et al., 2003). Candida albicans serve as an important opportunistic pathogen and exist as commensal in healthy human but not in immunocompromised patients as they possess a potential systemic infection due to their remarkable adaptation in the distinct host (Rosenbach et al., 2010). Candida albicans often recalcitrant to most of the therapy due to their ability to morphologically switch from yeast to pseudohyphae and also mixed infections with bacteria. However, their ability to form drug-resistant biofilm is the main successful factor in becoming the main etiologic agent of candidiasis (Ramage and Lopez-Ribot, 
2005). Further studies revealed that candida biofilms developed drug resistance towards the most commonly used antifungal agents, fluconazole and amphotericin B through the increasing of the maturation process and the presence of minimal matrix (Sardi et al., 2011). The prevalence of anti-candidal drug resistance demands an urgent search for new anti-candidal agents to tackle this bothersome situation. Despite the availability of numerous anti-candidal agents clinically in treating superficial and systemic candidiasis, there are very few classes that have been used widely including polyenes, flucytosine, and azoles due to their high toxicity (Kathiravan et al., 2012). Hence, endophytes from medicinal plants are depicted as an outstanding and safer source for antifungal drugs development as they might provide diverse and enormous phytochemical compounds that offer a great scope of novel antifungal lead (Turner et al., 2006), besides their lower toxicity as their compounds do not kill the eukaryotic host plant system (Alvin et al., 2014).

The intriguing finding from the current study is the fermentation broth of endophytic fungal isolate $C$. ramicola IBRLCM127 that was isolated from the rhizome of C. mangga exerted significant anti-candidal activity. The MIC and MYC values for C. albicans were found to be the same, viz., $2.5 \mathrm{mg} / \mathrm{ml}$, thus giving the ratios of 1 for MYC/MIC. According to Levison and Levison (2009), bactericidal drugs are those with minimal lethality concentration value same or not more than fourfold greater than their MIC values. Therefore, the activity of ethyl acetate extract from the current study can be regarded as fungicidal due to the fact that the ratio of MYC/MIC was $\leq 4$ (Table 2). Clinically, there has been an understandable concept that bactericidal drugs are more powerful antibiotic agents compared to bacteriostatic drugs as these classes of drugs can kill bacteria and rather effective in severely ill and immunocompromised patients (Fauci et al., 2008).

Candida albicans is one of the frequently isolated pathogenic fungi in human, especially those with immunodeficiency (Mohan, 2017). Candida albicans can be regarded as a polymorphic fungus as it able to grow in few distinct forms likes ovoid budding cell, pseudohyphae with ellipsoidal cells restricted at the septa, and true hyphae that possesses parallel walls (Berman and Sudbery, 2002). The pathogenicity and virulence of $C$. albicans are much related to the ability of cells to morph alternately between filamentous form and yeast. Both forms are found to be pathogenic, of which the filamentous form of hyphal cells plays a crucial role in infection process as it is more invasive than the yeast, while the yeast form plays key roles in dissemination (Dalle et al., 2010; Saville et al., 2003).

The complexity of lifestyle and virulence strategy in $C$. albicans has triggered profound research among the researchers to explore natural sources for the production of novel bioactive compounds with anti-candidal activity, especially the untapped endophytic fungi. Fungal endophytes have been acknowledged as an arsenal of novel biologically active substances for drug discovery (Okoye et al., 2015) of which only a handful from a million of fungal endophytes species have been explored so far. Therefore, it is believed that the further discovery of this untapped source might increase the possibility to discover novel bioactive natural products (Yu et al., 2010). The result from our study also indicated a significant anti-candidal activity exerted by ethyl acetate extract of C. ramicola IBRLCM127. There are also a few reports concerning this matter including the study conducted by Mittal et al. (2016) that was successfully isolated a novel compound of N- [(2S,3aR, 6S,7aS)-6- acetamido-octahydro-1,3-benzothiazol2-yl]2-(adamantan-1-yl) which derived from endophytic fungal Emericella sp. recovered from Azadirachta indica A. Juss (Neem) tree that showed a great potential in inhibiting the growth of $C$. albicans.

The photomicrographs from SEM and TEM confirm the most noteworthy morphological changes in some organelles and structures of $C$. albicans cells are caused by the ethyl acetate extract of $C$. ramicola IBRLCM127 that possesses anti-candidal activity. The activity of the extract suggests a potential mechanism to alter the components of the cell wall and cell membrane, inhibit DNA and protein synthesis, as well as enhance membrane permeability and cytoplasmic content leakage (Torey et al., 2016). A crude extract of $C$. ramicola IBRLCM127 contains several distinctive active compounds in which each of the compounds possesses different mechanisms of actions towards $C$. albicans cells. Therefore, the rigid cell walls of $C$. albicans which are made up mainly from chitins and glucans (Chaffin, 2008) offer a notion that some crude extract compounds are responsible to penetrate the cell wall while the other compounds are accountable in accessing further into the cell in order to cause severe damage.

The genomics and proteomics advancement gives solid evidence that yeast and fungi are sharing a common origin of their cell walls. Generally, yeast and fungal cell walls like other eukaryotic cell walls are made up of fibrous components such as protein and polysaccharide as well as a cross-linked amorphous matrix, i.e., glycoprotein, of which these chemical components are highly diverse in plant and fungal cell walls (Gonzalez et al., 2009). Fungal cell walls mainly composed of mannoproteins, chitins, and glucans with different proportions according to the species with $\beta$-1,3-glucan serves as a main cell wall component (Brown \& Gordon, 2003). However, there is slightly difference in the chitin concentration of fungi and yeast of which the chitin concentration in fungi is higher than in the yeast (Bernard and Latge, 2001). Both fungal and yeast cell walls are dynamic structure that gives protection to the cells for their viability during osmotic pressure and other environmental stresses, while at the same time permitting the cells interaction with their surrounding (Bowman and Free, 2006).

Up to now, many studies have been conducted to investigate the action mode of the endophytic fungal extract on the yeast and fungal cells with the emphasizing to the deformation or destruction of the cell wall and cell membrane (Kumari et al., 2018). The current results from showed that ethyl acetate extract of endophytic fungal $C$. ramicola IBRLCM127 impacted the cell wall synthesis and cell membrane permeability, congruent with Nath and Joshi (2017) that reported the presence of various cell deformities like wrinkled and disintegrated cell structures and disruption of cell wall after the exposure to the endophytic fungal extracts. Fungal cells are typically enclosed in a cell wall that serves as an essential structural support for cell protection. The fungal cell wall components of $\beta$-glucan and chitin contribute to the strengthening the cell wall shape of $C$. albicans, whereas mannoproteins responsible for permeability, antigenicity, and adherence (Cabib et al., 1988). Any disruption to the synthesis of these components can lead to the failure of the cell wall to 
protect the cell (Cabib et al., 1982). Meanwhile, the distortion of the fungal cell membrane by the extract could possibly due to the disruption of the ergosterol synthesis as cell membrane of the fungi is made up of unique ergosterol that assists in maintaining the structure and function of the plasma membrane. Interestingly, the absence of some yeast and fungal cell wall and cell membrane components in human such as $\beta$-glucan, chitin, and mannoproteins of the cell wall, as well as ergosterol of the cell membrane making them a vulnerable target that provide some selective and toxicity advantages over the modes of action of antifungal agents (Akins, 2005; Tada et al., 2013).

\section{CONCLUSION}

The ethyl acetate extract of endophytic fungal $C$. ramicola IBRLCM127 isolated from the rhizome of $C$. mangga exhibited significant anti-candidal activity. The extract was proven to exhibit fungicidal effect on the $C$. albicans cells and the structures of the cells were starting to collapse after 36 hours of exposure to the fungal extract. Further investigation in regard to the isolation and identification of the biologically active compounds inside the extract is necessary considering the fact that the discovery and development of a new antifungal drug are at a very slow pace despite the technological advancement.

\section{ACKNOWLEDGMENT}

RUI research grant scheme (ac: 1001/PBIOLOGI/811 326) from Universiti Sains Malaysia.

\section{CONFLICT OF INTEREST}

The authors declare that there are no conflicts of interest relevant to the contents of this article.

\section{REFERENCES}

Akins RA. An update on antifungal targets and mechanisms of resistance in Candida albicans. Med Mycol, 2005; 42:285-318.

Alvin A, Miller KI, Neilan BA. Exploring the potential of endophytes from medicinal plants as sources of antimycobacterial compounds. Microbiol Res, 2014; 169:483-95.

Berger RG. Biotechnology of flavours - the next generation. Biotechnol Lett, 2009; 31(11):1651-9.

Bernard M, Latge JP. Aspergillus fumigatus cell wall: composition and biosynthesis. Med Mycol, 2001; 39(1):9-17.

Borges M, Ven MAD, Cutsem, JV. Structural degeneration of Aspergillus fumigatus after exposure to superconazole. J Med Vet Mycol, 1989; 27:381-9.

Bowman SM, Free SJ. The structure and synthesis of the fungal cell wall. BioEssays, 2006; 28(8):799-808.

Brown GD, Gordon S. Fungal $\beta$-glucans and mammalian immunity. Immunity, 2003; 19(3):311-5.

Cabib E, Roberts RL, Bowers B. Synthesis of the yeast cell wall and its regulation. Annu Rev Biochem, 1982; 51:763-93.

Cabib E, Bowers B, Sburlati A, Silverman SJ. Fungal cell wall synthesis: the construction of a biological structure. Microbiol Sci, 1988; 5:370-5.

Chaffin WL. Candida albicans cell wall proteins. Microbiol Mol Biol Rev, 2008; 72(3):495-544.

Chapman B, Slavin M, Marriott D, Halliday C, Kidd S, Arthur I, Bak N, Heath CH, Kennedy K, Morrissey CO, Sorrel TC, van Hal S, Keighley C, Goeman E, Underwood N, Haikowicz K, Hofmeyr A, Leung M, Macesic N, Botes J, Blyth C, Cooley L, George CR, Kalukottege P, Kesson A, McMullan B, Baird R, Robson J, Korman TM, Pendle S, Weeks $\mathrm{K}$, Liu E, Cheong E, Chen S. Changing epidemiology of candidaemia in Australia. J Antimicrob Chemother, 2017; 72:1103-8.
Clinical and Laboratory Standards Institute. Performance standards for antimicrobial susceptibility testing; 16th informational supplement. M100-S16. Clinical and Laboratory Standards Institute, Wayne, PA, 2006.

Centers for Disease Control and Prevention. Fluconazoleresistant Candida. Antibiotic resistance threats in the United States. CDC, Georgia, USA, pp 63-64, 2013.

Dalle F, Wachtler B, L'Olivier C, Holland G, Bannert N, Wilson D, Labruere C, Bonnin A, Hube B. Cellular interactions of Candida albicans with human oral epithelial cells and enterocytes. Cell Microbiol, $2010 ; 12: 248-71$

Espinel-Ingroff A, Kish JCW, Kerkering TM, Fromtling RA, Bartizal K, Galgiani JN, Villareal K, Pfaller MA, Gerarden T, Rinaldi MG. Collaborative comparison of broth macrodilution and microdilution antifungal susceptibility tests. J Clin Microbiol, 1992; 30:3138-45.

Fauci AS, Kasper DK, Longo DL, Braunwald E, Hanser SL, Jameson JL, Loscalzo J. Harrison's principles of internal medicine. $17^{\text {th }}$ edition, McGraw-Hill Professional, New York, 2008.

Gonzalez M, de Groot PWJ, Klis FM, Lipke PN. Glycoconjugate structure and function in fungal cell walls. In: Moran A, Brennan P (eds.). Microbial glycobiology: structures, relevance, and applications. Elsevier, Amsterdam, The Netherlands, pp 1033-58, 2009.

Kathiravan MK, Salake AB, Chothe AS, Dudhe PB, Watode RP, Mukta MS, Gadhwe S. The biology and chemistry of antifungal agents: a review. Bioorgan Med Chem, 2012; 20:5678-98.

Kaufman CA. Candidiasis. Goldman's Cecil Medicine. 24th edition, vol. 2, pp 1986-90, 2012.

Kumari M, Taritla S, Sharma A, Jayabaskaran C. Antiproliferative and antioxidative bioactive compounds in extracts of marine-derived endophytic fungus Talaromyces purpureogenus. Front Microbiol, 2018; 9(1777)

Lam KS. New aspects of natural products in drug discovery. Trends Microbiol, 2007; 15:279-89.

Levison ME, Levison JH. Pharmacokinetics and pharmacodynamics of antibacterial agents. Infect Dis Clin North Am, 2009; 23(4):791-7.

Levy SB. Antibiotic resistance-the problem intensifies. Adv Drug Deliv Rev, 2005; 57:1446-50.

Maschmeyer, G. The changing epidemiology of invasive fungal infections: new threats. Int J Antimicrob Agents, 2006; 1:3-6.

Miceli MH, Diaz JA, Lee SA. Emerging opportunistic yeast infections. Lancet Infect Dis, 2011; 11(2):142-51.

Mittal S, Shrivastava D, Govill S, Kumar S, Bisen PS. A novel anticandidal compound containing sulfur from endophytic fungus Emericella sp. Nat Prod J, 2016; 6:1-6.

Mohan S. A study on clinical patterns of mucocutaneous candidiasis in immunosuppressed patients. Int J Dermatol Clin Res, 2017; 3(1):032-4.

Morrell M, Fraser VJ, Kollef MH. Delaying the empiric treatment of Candida bloodstream infection until positive blood culture results are obtained: a potential risk factor for hospital mortality. Antimicrob Agents Chemother, 2005; 49(9):3640-5.

Naglik JR, Moyes DL, Wachtler B, Hube B. Candida albicans interactions with epithelial cells and mucosal immunity. Microb Infect, 2011; 13(12-13):963-76.

Nath A, Joshi S. Anti-candidal effect of endophytic fungi isolated from Calotropis gigantean. Rev Biol Trop, 2017; 65(4):1437-47.

Nor Afifah S, Darah I, Shaida FS, Mohd Jain NMK, Nurul AZ. Antimicrobial activity of various extracts of a tropical Chlorophyta macroalgae, Halimeda discoidea. J Appl Sci, 2010; 10(23):3007-13.

Odds FC, Brown AJ, Gow NA. Antifungal agents: mechanisms of action. Trends Microbiol, 2003; 11:272-9.

Okoye FB, Nworu CS, Debbab A, Esimone CO, Proksch P. Two new cytochalasins from an endophytic fungus, KL-1.1 isolated from Psidium guajava leaves. Phytochem Lett, 2015; 14:51-5.

Patel SJ, Saiman L. Antibiotic resistance in neonatal intensive care unit pathogens: mechanisms, clinical impact, and prevention including antibiotic stewardship. Clin Perinatol, 2010; 37(3):547-63. 
Pfaller MA, Diekema DJ. Epidemiology of invasive candidiasis: a persistent public health problem. Clin Microbiol Rev, 2007; 20:133-63.

Ramage G, Lopez-Ribot JL. Techniques for antifungal susceptibility testing of Candida albicans biofilms. Methods Mol Med, 2005; 118:71-9.

Rosenbach A, Dignard D, Pierce JV, Whiteway M, Kumamoto CA. (2010). Adaptations of Candida albicans for growth in the mammalian intestinal tract. Eukaryotic Cell, 2010; 9(7):1075-86.

Sardi JC, Almeida AM, Mendes-Giannini MJ. New antimicrobial therapies used against fungi present in subgingival sites - a brief review. Arch Oral Biol, 2011; 56:951-9.

Saville SP, Lazzell AL, Monteagudo C, Lopez-Ribot JL. Engineered control of cell morphology in vivo reveals distinct roles for yeast and filamentous forms of Candida albicans during infection. Eukaryot Cell, 2003; 2:1053-60.

Sexton JA, Brown V, Johnston M. Regulation of sugar transport and metabolism by the Candida albicans Rgt1 transcriptional repressor. Yeast, 2007; 24(10):847-60.

Tada R, Latge JP, Aimanianda V. Undressing the fungal cell wall/cell membrane-the antifungal drug targets. Curr Pharm Des, 2013; 19:3738-47.

Tong WY, Chong, CL, Darah I, Latiffah Z. Enhancement of anti-candidal activity of endophytic fungus Phomopsis sp. ED2, isolated from Orthosiphon stamineus Benth, by incorporation of host plant extract in culture medium. J Microbiol, 2012; 50(4):581-5.
Torey A, Vijayarathna S, Jothy SL, Gothai S, Chen Y, Latha LY, Kanwar JR, Dharmaraj S. Sasidharana S. Exploration of the anticandidal mechanism of Cassia spectabilis in debilitating candidiasis. J Tradit Complement Med, 2016; 6(1):97-104.

Turner MS, Drew RH, Perfect JR. Emerging echinocandins for treatment of invasive fungal infections. Expert Opin Emerg Drugs, 2006; 11(2):231-50.

Yogalatha L, Darah I, Jain K, Sasidharan S. Toxicity of Vernonia cinerea. Pharma Boil, 2010; 48(1):101-4.

Yu H, Zhang L, Li I, Zheng C, Guo I, Li W, Sun P, Qin I. Recent developments and future prospects of antimicrobial metabolites produced by endophytes. Microbiol Res, 2010; 165:437-49.

How to cite this article:

Mu'azzam KAAR, Darah I. Ceratobasidium ramicola IBRLCM127, an endophytic fungus isolated from Curcuma mangga Valeton \& Zijp with strong anti-candidal activity. J Appl Pharm Sci, 2019; 9(11):086-092. 